\title{
Inhibitory kappa B alpha expression in endometriosis
}

\section{Endometrioziste inhibitör kappa B alfa ekspresyonu}

\author{
(1) Fabio Barra, (1) Lorenzo Ferro Desideri, (D) Carolina Scala, (1) Simone Ferrero \\ Academic Unit of Obstetrics and Gynecology, IRCCS Ospedale Policlinico San Martino; Department of Neurosciences, Rehabilitation, \\ Ophthalmology, Genetics, Maternal and Child Health (DiNOGMI), University of Genoa, Genoa, Italy
}

Keywords: Endometriosis, endometriotic implants, deep infiltrating endometriosis, inhibitory kappa B

Anahtar Kelimeler: Endometriozis, endometriotik implantlar, derin infiltran endometriozis, inhibitor kappa B

\section{To the Editor,}

We read with great interest the article by Arlier et al. ${ }^{(1)}$ entitled "Tumor necrosis factor alfa and interleukin 1 alfainduced phosphorylation and degradation of inhibitory kappa B (ІкB), alfa are regulated by estradiol $\left(E_{2}\right)$ in endometrial cells," published in your journal. Interestingly, the authors demonstrated that ectopic endometrium was significantly characterized by less immunoreactivity for ІкВ, a cytoplasmatic inhibitor of the transcription factor nuclear factor (NF)-кB, and that $\mathrm{E}_{2}$ might modulate its expression. The rational of this study is based on evidence of the critical role of NF-кB, which mediates gene transcription of several protein involved in inflammation, angiogenesis, as well as in proliferation and reduced apoptosis of endometriotic cells. A previous study reported that an excessive activation of NF-KB might be present in endometriotic implants of women affected by endometriosis ${ }^{(2)}$. For this reason, it might represent an interesting target for treating this benign chronic hormonal-dependent disease ${ }^{(3)}$. Although the authors should be congratulated for their laboratory findings, we would like to discuss some methodologic concerns of their study. In the material and methods, the authors described that the ectopic endometrial samples for western blot and immunocytochemical analysis were obtained from 6 women with endometriosis. First, the authors should add information on the severity of endometriosis for each patient in accordance with American Society of Reproductive Medicine classification. More importantly, the authors did not report from which sites the endometriotic implants were obtained, and in particular, if they originated from peritoneal nodules, ovarian endometriomas or deep infiltrating endometriosis (DIE) nodules. In general, it would be of particular interest to know if the activity of ІкB and the effect of $\mathrm{E}_{2}$ on its expression would be different in implants originating from these three distinguished phenotypes of endometriosis, which probably have different pathogeneses ${ }^{(4)}$. Regarding this aspect, it has been previously described that nodules of DIE may have higher proinflammatory reaction, higher vascularization, as well a higher density of nerve fibers, which may be responsible for a more aggressive clinical behavior ${ }^{(5)}$. Nevertheless, the results of the study by Arlier et al. ${ }^{(1)}$ are innovative and promising. Thus, in the near future, new studies are needed to better clarify the role ІкВ in inflammatory pathway of endometriotic cells. More importantly, it could be advisable to better understand if this protein may represent a suitable molecular target for a chronic medical therapy, which needs to balance clinical efficacy with cost and tolerability.

Ethics

Peer-review: External and internal peer-reviewed.

\section{Authorship Contributions}

Surgical and Medical Practices: S.F., Concept: F.B., S.F., Design: F.B., S.F., Data Collection or Processing: F.B., C.S., S.F.,

\footnotetext{
Address for Correspondence/Yazışma Adresi: Simone Ferrero, MD, PhD

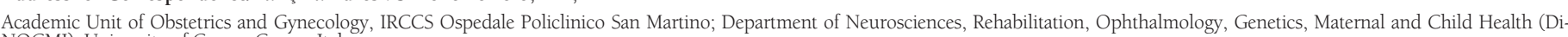
NOGMI), University of Genoa, Genoa, Italy

Phone: +39010 511525 E-mail: simoneferrero@me.com ORCID ID: orcid.org/0000-0003-2225-5568

Received/Geliș Tarihi: 03.05.2018 Accepted/Kabul Tarihi: 19.08.2018

${ }^{\circledR}$ Copyright 2018 by Turkish Society of Obstetrics and Gynecology

Turkish Journal of Obstetrics and Gynecology published by Galenos Publishing House
} 
Analysis or Interpretation: F.B., S.F., Literature Search: F.B., C.S., Writing: F.B., L.F.D., S.F.

Conflict of Interest: The authors reported no conflicts of interest.

Financial Disclosure: The paper was not funded.

\section{References}

1. Arlier S, Kayisli UA, Arici A: Tumor necrosis factor alfa and interleukin 1 alfa induced phosphorylation and degradation of inhibitory kappa $\mathrm{B}$ alpha are regulated by estradiol in endometrial cells. Turk J Obstet Gynecol 2018;15:50-59.
2. Kaponis A, Iwabe T, Taniguchi F, Ito M, Deura I, Decavalas G, Terakawa N, Harada T: The role of NF-kappaB in endometriosis. Front Biosci (Schol Ed) 2012;4:1213-1234.

3. Barra F, Scala C, Mais V, Guerriero S, Ferrero S: Investigational drugs for the treatment of endometriosis, an update on recent developments. Expert opinion on investigational drugs 2018;27:445-458.

4. Vercellini P, Vigano P, Somigliana E, Fedele L: Endometriosis: pathogenesis and treatment. Nature reviews Endocrinology 2014;10:261-275.

5. Ferrero S, Alessandri F, Racca A, Leone Roberti Maggiore U: Treatment of pain associated with deep endometriosis: alternatives and evidence. Fertility and sterility 2015;104:771-792. 